\title{
Environmental interaction, additive and non-additive genetic variability is involved in the expression of tissue and whole-plant heat tolerance in upland cotton (Gossypium hirsutum. L)
}

\author{
Hafeez-ur-Rahman \\ Cotton Research Institute, Ayub Agricultural Research Institute, Faisalabad, Pakistan.
}

\begin{abstract}
Heat tolerance is measured at tissue level by cellular membrane thermostability (CMT) and at the whole plant level by the heat tolerance index $(\mathrm{HTI})$. Eight upland cotton cultivars and 15 crosses were used to determine the type and extent of genetic variability associated with the expression of these traits between and within environments. Heat stress and non-stress conditions were used as the CMT environments and years for HTI. The wide variation in heterotic expression and combining ability effects observed for CMT and HTI suggest multigenic inheritance of these traits. Significant genetic variability across environments was evident but the traits were not highly heritable because of substantial environmental interaction. The available genetic variability included both additive and non-additive components, but the proportion of additive genetic variability was high for HTI. The parental cultivars CRIS-19 and CIM-448 were good donor parents for high CMT under heat-stressed conditions, and MNH-552 and N-Karishma under non-stressed conditions. Cultivar $\mathrm{FH}-634$ was a good donor parent for $\mathrm{HTI}$. The results show two types of general combining ability (GCA) inheritance among high CMT parents: positive GCA inheritance expressed by CRIS-19 in the presence of heat stress and MNH-552 and N-Karishma in the absence of heat stress; and negative GCA inheritance expressed by $\mathrm{FH}-900$ in the presence of heat stress. It was also evident that genes controlling high CMT in cultivar CRIS-19 were different from those present in the MNH-552, N-Karishma and FH-900 cultivars. Similarly, among high $\mathrm{HTI}$ parents, $\mathrm{FH}-634$ showed positive and CIM-443 negative GCA inheritance. No significant relationship due to genetic causes existed between tissue and whole plant heat tolerance, diminishing the likelihood of simultaneous improvement and selection of the two traits.
\end{abstract}

Key words: cotton, environmental interaction, genetic variability, heat tolerance, membrane stability.

Received: March 11, 2005; Accepted: December 6, 2005.

\section{Introduction}

Heat stress primarily affects photosynthetic activity (Berry and Bjorkman, 1980) and cellular membranes (Raison et al., 1980), but its ultimate economic effect is reduced yield. Development of heat tolerance in commercially important crops like cotton is, therefore, necessary to sustain production, particularly in heat-stressed regions, and tissue and whole plant heat tolerance are important components of heat resistance in upland cotton (Rahman, 2004; Rahman et al., 2004). Screening whole plants for the degree of flowering and fruit-set in hot environments has been effective in improving heat tolerance in Gossypium barbadense L. (Feaster and Turcotte, 1985; Lu, and Zeiger, 1994). For other crop species, success with whole plant screening approaches has been achieved in tomato (Stevens, 1979;

Send correspondence to Hafeez-ur-Rahman. Cotton Research Institute, Ayub Agricultural Research Institute, Jhang road, 38950 Faisalabad, Pakistan. E-mail: hafeez_rahman@yahoo.co.uk.
Villareal and Lai, 1979), common bean (Dickson and Petzoldt, 1989) and cowpea (Hall, 1992, 1993). Whole plant screening techniques are usually empirical approaches requiring suitable screening environments for successful selections, and the presence of genotype $\mathrm{x}$ environment interaction often reduces selection efficiency in such approaches. The cellular membrane thermostability (CMT) assay (Sullivan, 1972; Sullivan and Ross, 1979) is an indirect screening technique for heat tolerance and also provides a reliable measure of tissue tolerance to heat stress (Raison et al., 1980, Blum and Ebercon, 1981). The CMT assay has been successfully used to identify heat tolerant and susceptible genotypes in several crop species, including cotton (Rahman et al., 2004). Information on the genetic behavior of CMT and HTI in upland cotton has not been established but is imperative to understanding the genetic bases of the two traits and providing theoretical grounds for applied cotton breeding programs. 
The objectives of the present study were to evaluate the effect of the environment on the available genetic variability associated with tissue and whole plant heat tolerance to decide on their potential as breeding objectives, and to evaluate the relative worth of upland cotton cultivars in terms of their combining ability effects for the two traits.

\section{Materials and Methods}

\section{Plant material}

Eight upland cotton (Gossypium hirsutum. L) cultivars were selected after a preliminary screening experiment carried out in 1998 (Rahman, 2004) at Cotton Research Institute (CRI), Faisalabad, Pakistan. During the 1999 crop season $15 \mathrm{~F}_{1}$ crosses were obtained in a line $\mathrm{x}$ tester pattern using 5 cultivars (serial numbers 1 to 5 in Table 4 ) as female lines, and 3 cultivars (serial numbers 6 to 8 in Table 4 ) as male testers.

\section{Cultivation conditions and experimental design}

Experiments in the field were sown on the 7 April and 29 May 2000, and 15 April and 4 June in 2001 at CRI. Early sowing in both the years (referred to as the April regime) helped in synchronizing the maximum flowering period of the crop with the highest temperatures of the year during June to July, and the later sowing (the June regime) with the optimum temperatures of August and September. Maximum and minimum temperatures during the April regime were significantly higher than those prevalent in the June regimes (data not shown), the April regimes being referred to as the heat-stressed field regimes and the June regimes as non-stressed. The soil of the experimental plots had a loamy texture with a $\mathrm{pH}$ of $8.5,0.92 \%$ organic matter and a 27 -saturation percentage. A randomized complete block experimental design with 3 replications was used for both sowing dates and years. Each entry per replication was represented by a single 4.5 -meter long row, with a row to row distance of $75 \mathrm{~cm}$ and a plant-to-plant distance of $30 \mathrm{~cm}$. Seed was soaked in tap water for six hours before sowing and three seeds were sown per hill in a well-prepared soil at field capacity. Plants were thinned to a uniform stand of single plant per hill when they attained about $15 \mathrm{~cm}$ in height. The noonday photosynthetically active radiation (PAR) ranged from 1800 to $2000 \mu \mathrm{mol} \mathrm{m}^{-2} \mathrm{~s}^{-1}$ during the April regime and 1600 to $2000 \mu \mathrm{mol} \mathrm{m}^{-2} \mathrm{~s}^{-1}$ in the June regime during maximum flowering period. Experiments were terminated 180 days after sowing (DAS) in both regimes and years. Both experiments (regimes) in a year received identical agronomic treatments. Experiments were fertilized with N:P:K at a rate of 150:50:00 kg per hectare. Potash (K) was not added as the pre-experiment soil test showed $145 \mathrm{ppm}$ potassium in the experimental field. Nitrogen application was split into three equal doses and applied at sowing, first irrigation (33-35 DAS) and maximum flowering. Experiments were sprayed for proper insect con- trol. Adequate irrigation was applied when necessary to eliminate the confounding effect of drought, especially during the reproductive stage.

Tissue tolerance to heat stress was assessed by the in vitro cellular membrane thermostability (CMT) assay which provides a measure of relative cell injury (RCI), a low RCI value indicating higher CMT and vice versa. Details of the procedure as standardized for upland cotton is reported elsewhere (Rahman et al., 2004). Cellular membrane thermostability was determined for all the genotypes at both sowing dates (temperature regimes) during 2001. Assessment of whole plant heat tolerance in both the years was based on the heat tolerance index (HTI), obtained from the ratio of seed cotton yield produced by a genotype under the heat stressed (April) and non-stressed (June) regimes.

\section{Statistical and biometric analyses}

Analysis of variance (ANOVA) was carried out in a factorial arrangement. Temperature regimes were treated as environments for CMT and years for HTI, respectively. All effects were assumed fixed. Parental cotton cultivars and their $F_{1}$ crosses were analyzed separately. Combining ability analyses were carried out using the procedure of Kempthorne (1957) assuming an inbreeding coefficient of $\mathrm{F}=1$. Variation due to crosses was partitioned into variation due to lines, testers (general combining ability, GCA) and lines $\mathrm{x}$ testers (specific combining ability, SCA). General combining ability is the average performance of a parental cultivar in a series of crosses and estimates the proportion of additive genetic variability, whereas, specific combining ability is the performance of a parental cultivar in a specific cross combination and helps to provide a measure of non-additive genetic variability. Estimates of genetic variability $\left(\sigma^{2} \mathrm{G}\right)$ were obtained across environments using temperature regime and years interactions as environments (Rahman, 2004). Heterosis $\left(\mathrm{H}_{\mathrm{F} 1}\right)$ was calculated in relation to mid parent and t-statistics was used to determine whether the $F_{1}$ hybrid mean significantly differed from the mid-parent value. The degree of dominance (DD) associated with each cross was determined by calculating the potence ratio $\left(\mathrm{F}_{1}-\mathrm{MP}\right) /(\mathrm{BP}-\mathrm{MP})$, where $\mathrm{F}_{1}$ is the mean performance of $F_{1}$ generation, while MP and $\mathrm{BP}$ is the mean performance of mid-parent and the better parent, respectively. Phenotypic and genetic correlation coefficients between CMT and HTI were determined using the method of Kwon and Torrie (1964).

\section{Results}

Parental cultivars differed significantly $(\mathrm{p}<0.01)$ for the phenotypic expression of tissue tolerance to heat stress as measured by CMT (Table 1). The parents $\mathrm{x}$ temperature regime interaction was non-significant $(p>0.05)$, indicating that the relative ranking among parental cultivars for CMT remained consistent across temperature regimes in 
Table 1 - Mean squares from the analyses of variance for phenotypic differences among parental upland cotton cultivars for cellular membrane thermostability (CMT) as measured by relative cell injury (RCI) across temperature regimes and heat tolerance index (HTI) across years.

\begin{tabular}{lccc}
\hline Source & df & RCI mean squares & HTI mean squares \\
\hline Replications & 2 & $10.70^{\mathrm{ns}}$ & $3.86^{\mathrm{ns}}$ \\
Temp. regimes (R) & 1 & $14.82^{\mathrm{ns}}$ & $7672.61^{* *}$ \\
Parents $(\mathrm{P})$ & 7 & $884.93^{* *}$ & $770.87^{* *}$ \\
P x R & 7 & $101.26^{\mathrm{ns}}$ & $719.18^{* *}$ \\
Residuals & 30 & 118.68 & 80.96 \\
\hline Total & 47 & & \\
\hline phenotypic & & $294.97 \pm 5.81$ & $256.96 \pm 15.48$ \\
variability $\left(\sigma_{\mathrm{P}}^{2}\right)$ & & $130.61 \pm 2.00$ & $8.62 \pm 2.45$ \\
genotypic & & & \\
variability $\left(\sigma_{\mathrm{G}}^{2}\right)$ & & $0.443 \pm 0.007$ & $0.033 \pm 0.009$ \\
$\sigma_{\mathrm{G}}^{2}: \sigma_{\mathrm{P}}^{2}$ &
\end{tabular}

*significant at $\mathrm{p}<0.05 ; * *$ significant at $\mathrm{p}<0.01 ; \mathrm{ns}=$ non-significant at $\mathrm{p}>0.05 ; \mathrm{df}=$ degrees of freedom.

the field. Estimates of genetic variability and broadsense CMT heritability in parental cultivars were significant $(p<0.01)$ but, conversely, the years effect was not only a significant source of variation $(p<0.01)$ but it also significantly modified the relative HTI ranking among parental cultivars (Table 1). Estimates of genetic variability and broadsense heritability across environments were low due to the high magnitude of the parents $\mathrm{x}$ years interaction but were statistically significant $(\mathrm{p}<0.01)$.

Mean squares due to crosses $\mathrm{x}$ temperature regime interaction for CMT and crosses $\mathrm{x}$ years interaction for HTI were significant $(p<0.01)$. Correlation coefficients between mean CMT under heat stressed and non-stressed regimes and that between mean HTI in the two years were moderate $\left(r=0.47^{* *}\right.$ and $0.43^{* *}$, respectively; $\left.\mathrm{df}=43\right)$, indicating that the intensity of these interactions was moderately high. Genetic variability among crosses for CMT and HTI was moderately low in magnitude, but significant $(p<0.01)$. Further partitioning of interaction variance revealed significant lines $\mathrm{x}$ temperature regimes interaction for CMT $(\mathrm{p}<0.01)$, and lines $\mathrm{x}$ years and testers $\mathrm{x}$ years interactions for HTI $(p<0.01)$. This indicated that general combining ability (GCA) variation contributed by lines for CMT and that contributed by lines as well as testers for HTI varied across environments. Variation due to lines $\mathrm{x}$ testers $\mathrm{x}$ temperature regimes for CMT and lines $\mathrm{x}$ testers $\mathrm{x}$ years for HTI were non-significant ( $p>0.05)$, indicating that specific combining ability (non-additive genetic variability) for both CMT and HTI remained consistent across environments (Table 2). Quantitatively, GCA (from lines and testers together) accounted for $39 \%$ and SCA $61 \%$ of the total genotypic variability for CMT across temperature regimes. Likewise, the relative contribution to total genotypic vari-
Table 2 - Mean squares from the analyses of variance of combining ability in crosses of upland cotton for cellular membrane thermostability (CMT) as measured by relative cell injury ( $\mathrm{RCI}$ ) across temperature regimes and heat tolerance index (HTI) across years.

\begin{tabular}{|c|c|c|c|}
\hline Source & df & RCI mean squares & HTI mean squares \\
\hline Temp. regimes $(\mathrm{R})$ & 1 & $29.63^{\mathrm{ns}}$ & $1344.22 * *$ \\
\hline Crosses (C) & 14 & $461.50 * *$ & $2293.10 * *$ \\
\hline Lines (L) & 4 & $320.64 * *$ & $4653.84 * *$ \\
\hline Testers (T) & 2 & $624.97 * *$ & $3054.34 * *$ \\
\hline Lines x Testers & 8 & $491.04 * *$ & $922.42 * *$ \\
\hline $\mathrm{C} \times \mathrm{R}$ & 14 & $132.25 * *$ & $661.39 * *$ \\
\hline $\mathrm{L} \times \mathrm{R}$ & 4 & $282.24 * *$ & $734.86^{* *}$ \\
\hline $\mathrm{T} \times \mathrm{R}$ & 2 & $125.87^{\mathrm{ns}}$ & $1687.86^{* *}$ \\
\hline $\mathrm{L} \times \mathrm{T} \times \mathrm{R}$ & 8 & $58.85^{\mathrm{ns}}$ & $368.03^{\mathrm{ns}}$ \\
\hline Residuals & 58 & 47.33 & 191.81 \\
\hline Total & 89 & & \\
\hline $\begin{array}{l}\text { phenotypic } \\
\text { variability }\left(\sigma_{\mathrm{P}}^{2}\right)\end{array}$ & & $153.83 \pm 6.64$ & $764.36 \pm 14.85$ \\
\hline $\begin{array}{l}\text { genotypic } \\
\text { variability }\left(\sigma_{G}^{2}\right)\end{array}$ & & $54.87 \pm 1.13$ & $271.95 \pm 2.44$ \\
\hline$\sigma_{\mathrm{G}}^{2}: \sigma_{\mathrm{P}}^{2}$ & & $0.356 \pm 0.007$ & $0.356 \pm 0.003$ \\
\hline
\end{tabular}

*significant at $\mathrm{p}<0.05 ; * *$ significant at $\mathrm{p}<0.01 ; \mathrm{ns}=$ non-significant at $\mathrm{p}>0.05 ; \mathrm{df}=$ degrees of freedom; $\pm=$ standard error.

ability for HTI across years was $77 \%$ for GCA and $23 \%$ for SCA.

Since the crosses $\mathrm{x}$ temperature regime interaction for $\mathrm{CMT}$ and the crosses $\mathrm{x}$ years interaction for HTI were significant, combining ability variations for the two traits were also studied under individual environments (Table 3). The data showed that variation caused by lines, testers and lines $\mathrm{x}$ testers was significant $(\mathrm{p}<0.01)$ for CMT under both heat stressed and unstressed regimes, suggesting that both general and specific combining ability variations were involved in the inheritance of CMT. Quantitatively, relative contribution of GCA (from lines and testers together) to total genetic variability for CMT was $45 \%$ under heat stressed regime and $49 \%$ under unstressed (June) regime. The relative contribution of female parents (lines) decreased from $37 \%$ in the absence of heat stress to $20 \%$ under heat stress (Figure 1) but, conversely, the relative contribution of male parents (testers) increased to $25 \%$ under heat stress as compared to 12 percent in the absence of heat stress. This suggested that heat stress produced a favorable environment for the expression of genes controlling CMT in male parents and the absence of heat stress for those controlling CMT in female parents. The relative contribution of specific combining ability (SCA) decreased from 55\% under heat stress to $51 \%$ under unstressed conditions. Regarding HTI, variation due to lines as well as lines $\mathrm{x}$ testers was significant $(p<0.01)$ in both crop years. Variation due to testers was significant only in the 2000 crop year (Table 3 ). In quantitative terms, GCA accounted for $83 \%$ of the to- 
Table 3 - Mean squares from the analyses of variance of combining ability in crosses of upland cotton for cellular membrane thermostability (CMT) as measured by relative cell injury (RCI) in April and June temperature regimes and heat tolerance index (HTI) in 2000 and 2001 crop years.

\begin{tabular}{|c|c|c|c|c|c|}
\hline \multirow[t]{2}{*}{ Source } & \multirow[t]{2}{*}{ df } & \multicolumn{2}{|c|}{ RCI mean squares } & \multicolumn{2}{|c|}{ HTI mean squares } \\
\hline & & April 2001 & June 2001 & Year 2000 & Year 2001 \\
\hline Replications & 2 & $41.34^{\mathrm{ns}}$ & $6.01^{\mathrm{ns}}$ & $1036.21 * *$ & $551.35^{*}$ \\
\hline Crosses & 14 & $270.22 * *$ & $323.52 * *$ & $1567.33 * *$ & $1387.16^{* *}$ \\
\hline Lines & 4 & $186.92 * *$ & $415.96^{* *}$ & $2243.69 * *$ & $3145.02 * *$ \\
\hline Testers & 2 & $470.42 * *$ & $280.41 * *$ & $4623.26^{* *}$ & $118.96^{\mathrm{ns}}$ \\
\hline Lines $\mathrm{x}$ Testers & 8 & $261.82 * *$ & $288.07 * *$ & $465.17 * *$ & $825.28^{* *}$ \\
\hline Residuals & 28 & 39.47 & 42.73 & 118.92 & 167.73 \\
\hline Total & 44 & & & & \\
\hline $\mathrm{PCV} \%$ & & 13.87 & 15.43 & 29.72 & 41.65 \\
\hline GCV\% & & 12.82 & 14.37 & 28.57 & 48.41 \\
\hline
\end{tabular}

*significant at $\mathrm{p}<0.05 ; * *$ significant at $\mathrm{p}<0.01 ; \mathrm{ns}=$ non-significant at $\mathrm{p}>0.05 ; \mathrm{df}=$ degrees of freedom; $\mathrm{PCV}=$ phenotypic coefficient of variability.

tal genetic variability for HTI during 2000 and $66 \%$ during 2001. Likewise, SCA accounted for $17 \%$ total HTI genetic variability in 2000 and $34 \%$ in 2001 . The results suggested that although SCA (non-additive) type of genetic variability was significantly involved, GCA (additive) type genetic variability was more important in the inheritance of HTI. The relative contribution of males (lines) to total genotypic variation in HTI increased from $41 \%$ in 2000 to $65 \%$ in 2001. Correspondingly, the relative contribution of male parents (testers) decreased from $42 \%$ in 2000 to only $1 \%$ in 2001 (Figure 1). Moreover, the coefficient of genetic variability (GCV\%) for HTI varied from $28 \%$ in 2000 to $48 \%$ in the 2001 crop season, indicating that genetic variability for HTI was comparatively less stable across environments. The 2000 crop year was more favorable from the breeding point of view because GCA variation expressed by both male and female parents was high and enhanced selection

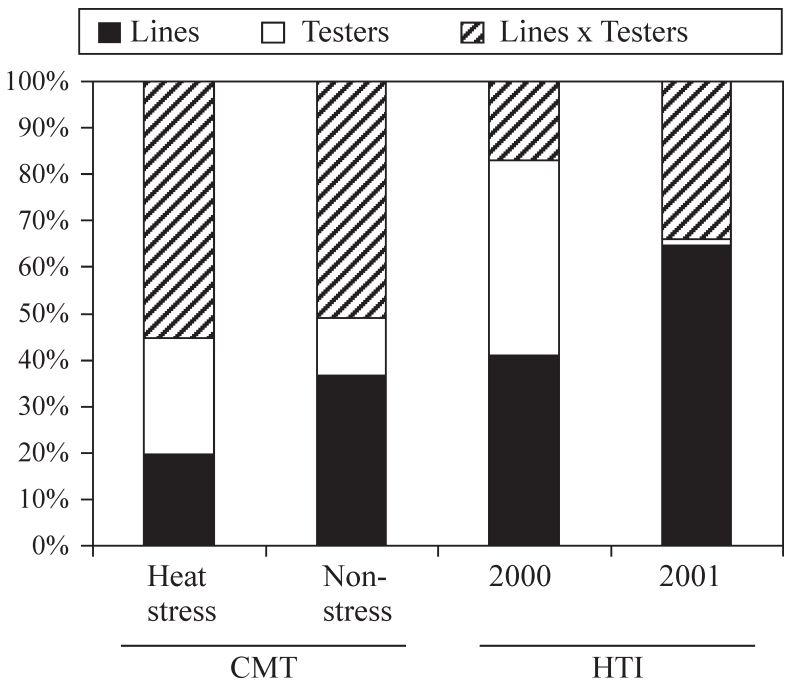

Figure 1 - Relative contribution of lines (females), testers (males) and lines $\mathrm{x}$ testers to total genotypic variation in cellular membrane thermostability (CMT) and heat tolerance index (HTI). efficiency in predominantly self-pollinated cotton genotypes.

The GCA effects expressed by various parental cultivars also varied across environments (Table 4). The parental cultivars CIM-448 and CRIS-19 were the main contributors to positive GCA variation for CMT (negative for RCI) under the heat-stressed regime and the cultivars MNH-552 and NIAB-Karishma under the unstressed regime. Among high CMT (low RCI) parental cultivars the CRIS-19 cultivar showed a significantly positive GCA effect for CMT $(p<0.01)$ under the heat-stressed regime and the MNH-552 and NIAB-Karishma cultivars under the unstressed regime (Table 4). Despite possessing high CMT, FH-900 cultivar expressed a significantly negative GCA effect for CMT under the heat-stressed regime, suggesting that genes controlling high CMT in FH-900 could not be expressed in its progenies. This could be due to the recessive nature of such genes or the absence of a favorable environment. The results thus revealed two types of GCA inheritance among high CMT parents, the positive GCA inheritance expressed by cultivar CRIS-19 in the presence of heat stress and MNH-552 and NIAB-Karishma in the absence of heat stress, and the negative GCA inheritance expressed by FH-900 in the presence of heat stress. This is evidence that genes controlling high CMT in the CRIS-19 cultivar were different from those present in FH-900, MNH-552 and NIAB-Karishma cultivars. Still another set of genes controlling high CMT was evident in the CIM-448 parental cultivar, which was a low CMT parent under both regimes but expressed a significantly positive GCA effect under the heat-stressed regime and a significantly negative effect under the unstressed regime (Table 4). The results, however, suggested that 'CRIS-19' and 'CIM-448' could prove good donor parents for high CMT under heatstressed conditions, and 'MNH-552' and 'NIAB-Karishma' under unstressed conditions. 
Table 4 - Estimates of general combining ability (GCA) effects for cellular membrane thermostability (CMT) as measured by relative cell injury (RCI) in April and June temperature regimes and heat tolerance index (HTI) in 2000 and 2001 crop years.

\begin{tabular}{|c|c|c|c|c|c|c|c|c|c|}
\hline \multirow{3}{*}{\multicolumn{2}{|c|}{$\begin{array}{l}\text { Parental } \\
\text { cultivars }\end{array}$}} & \multicolumn{4}{|c|}{ RCI } & \multicolumn{4}{|c|}{ HTI } \\
\hline & & \multicolumn{2}{|c|}{ April 2001} & \multicolumn{2}{|c|}{ June 2001} & \multicolumn{2}{|c|}{ April 2000} & \multicolumn{2}{|c|}{ June 2001} \\
\hline & & \multirow{2}{*}{$\frac{\text { GCA }}{+0.326^{\text {ns }}}$} & \multirow{2}{*}{$\begin{array}{l}\text { Mean } \\
71.54\end{array}$} & \multirow{2}{*}{$\frac{\text { GCA }}{-4.049^{\mathrm{ns}}}$} & \multirow{2}{*}{$\begin{array}{l}\text { Mean } \\
74.38\end{array}$} & \multirow{2}{*}{$\frac{\text { GCA }}{17.20^{* *}}$} & \multirow{2}{*}{$\begin{array}{c}\text { Mean } \\
81.50\end{array}$} & \multirow{2}{*}{$\frac{\text { GCA }}{30.90 * *}$} & \multirow{2}{*}{$\begin{array}{l}\text { Mean } \\
58.51\end{array}$} \\
\hline 1 & FH-634 & & & & & & & & \\
\hline 2 & FH-900 & $+5.959 * *$ & 60.84 & $-0.198^{\text {ns }}$ & 58.40 & $3.05^{\mathrm{ns}}$ & 73.79 & $-5.39^{\mathrm{ns}}$ & 44.12 \\
\hline 3 & MNH-552 & $-2.344^{\mathrm{ns}}$ & 57.85 & $-8.744 *$ & 65.50 & $-25.04 * *$ & 70.88 & $-17.51 * *$ & 45.97 \\
\hline 4 & CIM-448 & $-6.106^{* *}$ & 85.13 & $+4.545^{*}$ & 86.45 & $7.56^{*}$ & 73.81 & $-10.13^{*}$ & 33.07 \\
\hline 5 & CIM-443 & $+2.165^{\mathrm{ns}}$ & 78.63 & $+8.446^{*}$ & 72.56 & $-2.77^{\mathrm{ns}}$ & 83.37 & $2.13^{\text {ns }}$ & 79.41 \\
\hline 6 & N-Karishma & $-2.582^{\mathrm{ns}}$ & 61.60 & $-4.696 * *$ & 49.48 & $-3.51^{\mathrm{ns}}$ & 86.54 & $-1.76^{\mathrm{ns}}$ & 28.55 \\
\hline 7 & CRIS-19 & $-3.843 * *$ & 47.20 & $+0.879^{\mathrm{ns}}$ & 57.76 & $19.05^{* *}$ & 73.51 & $3.25^{\mathrm{ns}}$ & 86.64 \\
\hline \multirow[t]{5}{*}{8} & HR109-RT & $+6.425 * *$ & 84.60 & $+3.817^{*}$ & 73.97 & $-15.53 * *$ & 71.91 & $-1.48^{\mathrm{ns}}$ & 36.67 \\
\hline & $S E G C A$ (Lines) & 2.094 & & 2.179 & & 3.63 & & 4.32 & \\
\hline & $S E G C A$ (Tester) & 1.622 & & 1.688 & & 2.81 & & 3.34 & \\
\hline & Over all mean & & 68.42 & & 67.31 & & 76.91 & & 51.62 \\
\hline & $C D 5 \%$ & & 9.61 & & 19.38 & & 10.39 & & 16.11 \\
\hline
\end{tabular}

*significant at $\mathrm{p}<0.05 ; * *$ significant at $\mathrm{p}<0.01 ; \mathrm{ns}=$ non-significant at $\mathrm{p}>0.05 ; \mathrm{df}=$ degrees of freedom; $\mathrm{SE}=$ standard error. $\mathrm{CD} 5 \%=$ critical difference for significance at $5 \%$ level of probability.

Regarding HTI, parental cultivars FH-634, CRIS-19 and CIM-448 predominantly contributed to positive GCA variation during the 2000 trials (Table 4) but during 2001 only FH-634 showed a significantly positive GCA effect for HTI, indicating positive GCA inheritance. General combining ability (GCA) effects expressed by parental cultivars were not related to their mean HTI per se. Cultivar CRIS-19 showed a significantly positive GCA effect during 2000 and above average HTI during 2001, while cultivar CIM-448 had below average HTI in both years but showed a significantly positive GCA effect during 2000 $(\mathrm{p}<0.05)$ and significantly negative effect during 2001 $(\mathrm{p}<0.01)$. Cultivar CIM-443 also showed above average HTI in both the years but could not express high GCA effects and exhibited a negative GCA inheritance pattern. These results provided evidence that different sets of genes were involved in the expression of high HTI in cultivars FH-634, CIM-448, CIM-443 and CRIS-19. Interestingly, cultivars $\mathrm{MNH}-552$ and NIAB-Karishma, which showed high GCA effects for CMT, did not show high GCA effects for HTI. Cultivars CRIS-19, NIAB-Karishma and CIM448 could, however, express high mean or GCA effect for both CMT and HTI in at least one of the two environments (Table 4).

Since specific combining ability (SCA) variations for CMT and HTI did not show significant interaction with the environments (Table 2), SCA effects, mid parent heterosis and degree of dominance expressed by various cross combinations were computed on the pooled data (Table 5). It was obvious from the data that good specific combinations for CMT were either a product of good $\mathrm{x}$ poor or poor $\mathrm{x}$ good general combiner, except $\mathrm{C} 47$, which was a product of two good general combiners (CIM-448 and CRIS-19) under the heat stressed regime. All good specific combinations for CMT showed an over-dominance type of gene effect, except $\mathrm{C} 47$, which expressed partial-dominance. Relatively fewer good specific combinations were evident for HTI, although all cross combinations expressed significant mid-parent heterosis (Table 5). Only two cross combinations (C17 and $\mathrm{C} 38)$ expressed significantly positive SCA effects for HTI. Over dominance appeared to be responsible for the heterotic expression of HTI in $\mathrm{C} 17$ and partial dominance in C38. Cross combination, C26 and $\mathrm{C} 36$, respectively, exhibited the highest positive and negative dominance deviations for HTI.

No significant level of phenotypic or genotypic association between tissue and whole plant heat tolerance could be detected (Figure 2). The magnitudes of phenotypic and genotypic correlations were, however, relatively higher in parental cultivars than in crosses. This could be due to the higher level of gene fixation in parental cultivars because of generations of self-pollination.

\section{Discussion}

The presence of significant differences between cotton cultivars as well as crosses for cellular membrane thermostability (CMT) and heat tolerance index (HTI) signifies that heat tolerance at tissue and whole plant levels are genetically determined and thus liable to genetic improvement. A significant level of genetic variability for CMT has also been reported in wheat (Blum et al., 2001; Ibrahim and Quick, 2001a and b; Saadallah 1990), Soybean (Martineau et al., 1979) and groundnut (Talwar et al., 2002). The available genetic variability for CMT in upland cotton carried 
Table 5 - Estimates of specific combining ability (SCA) effects, mid parent heterosis $\left(\mathrm{H}_{\mathrm{F} 1}\right)$, potence ratio (PR), and degree of dominance (DD) for cellular membrane thermostability (CMT) as measured by relative cell injury (RCI) in April and June temperature regimes and heat tolerance index (HTI) in 2000 and 2001 crop years.

\begin{tabular}{|c|c|c|c|c|c|c|c|c|}
\hline \multirow[t]{2}{*}{ Cross } & \multicolumn{4}{|c|}{ RCI } & \multicolumn{4}{|c|}{ HTI } \\
\hline & SCA & $\mathrm{H}_{\mathrm{F} 1}$ & PR & DD & SCA & $\mathrm{H}_{\mathrm{F} 1}$ & PR & $\mathrm{DD}$ \\
\hline $\mathrm{C} 16$ & $4.97^{\mathrm{ns}}$ & $0.84^{\mathrm{ns}}$ & 0.09 & Add & $3.23^{\mathrm{ns}}$ & $34.59 * *$ & 5.44 & Over \\
\hline $\mathrm{C} 17$ & $-10.06^{* *}$ & $-20.80 * *$ & -1.05 & Over & $16.17 * *$ & $39.62 * *$ & 9.78 & Over \\
\hline $\mathrm{C} 18$ & $5.09^{\mathrm{ns}}$ & $-3.33 * *$ & -0.78 & Partial & $-19.40 * *$ & $9.98 * *$ & 0.88 & Partial \\
\hline $\mathrm{C} 26$ & $-9.27 * *$ & $-4.14 * *$ & -1.12 & Over & $2.38^{\mathrm{ns}}$ & $18.46^{* *}$ & 19.39 & Over \\
\hline $\mathrm{C} 27$ & $5.27^{\mathrm{ns}}$ & $22.15^{* *}$ & 4.47 & Over & $-12.01 *$ & $1.90 * *$ & 0.13 & Add \\
\hline $\mathrm{C} 28$ & $4.00^{\mathrm{ns}}$ & $10.19 * *$ & 0.80 & Partial & $9.63^{\text {ns }}$ & $22.28^{* *}$ & 6.96 & Over \\
\hline $\mathrm{C} 36$ & $3.49^{\mathrm{ns}}$ & $1.72 * *$ & 0.33 & Add & $-7.91^{\mathrm{ns}}$ & $-41.23 * *$ & -40.68 & Over \\
\hline C37 & $5.41^{\text {ns }}$ & $10.40^{* *}$ & 1.44 & Over & $-4.35^{\mathrm{ns}}$ & $-18.54 * *$ & -1.00 & Complete \\
\hline C38 & $-8.90 * *$ & $-25.84 * *$ & -1.64 & Over & $12.26^{*}$ & $-1.78^{* *}$ & -0.48 & Partial \\
\hline $\mathrm{C} 46$ & $0.51^{\mathrm{ns}}$ & $-15.06^{* *}$ & -0.61 & Partial & $6.70^{\mathrm{ns}}$ & $26.63 * *$ & 9.72 & Over \\
\hline $\mathrm{C} 47$ & $-8.30^{* *}$ & $-26.25^{* *}$ & -0.86 & Partial & $-1.21^{\mathrm{ns}}$ & $18.14^{* *}$ & 1.11 & Over \\
\hline $\mathrm{C} 48$ & $7.79^{*}$ & $-6.57 * *$ & -1.56 & Over & $-5.50^{\mathrm{ns}}$ & $6.48^{* *}$ & 8.83 & Over \\
\hline C56 & $0.30^{\mathrm{ns}}$ & $2.55^{* *}$ & 0.17 & Partial & $-4.40^{\mathrm{ns}}$ & $-6.04 * *$ & -0.33 & Add \\
\hline $\mathrm{C} 57$ & $7.68^{*}$ & $16.65^{* *}$ & 1.11 & Over & $1.40^{\mathrm{ns}}$ & $5.16^{* *}$ & 6.69 & Partial \\
\hline $\mathrm{C} 58$ & $-7.98 *$ & $-14.26^{* *}$ & -5.25 & Over & $3.01^{\mathrm{ns}}$ & $-1.14 * *$ & -0.06 & Add \\
\hline SE SCA & 3.09 & & & & 5.61 & & & \\
\hline SE sij-skl & 4.37 & & & & 7.94 & & & \\
\hline Average & & -3.45 & & & & .63 & & \\
\hline
\end{tabular}

*significant at $\mathrm{p}<0.05 ; * *$ significant at $\mathrm{p}<0.01 ; \mathrm{ns}=$ non-significant at $\mathrm{p}>0.05 ; \mathrm{df}=$ degrees of freedom; $\mathrm{SE}=$ standard error; $\mathrm{SE}$ sij-skl $=$ standard error for two specific crosses.

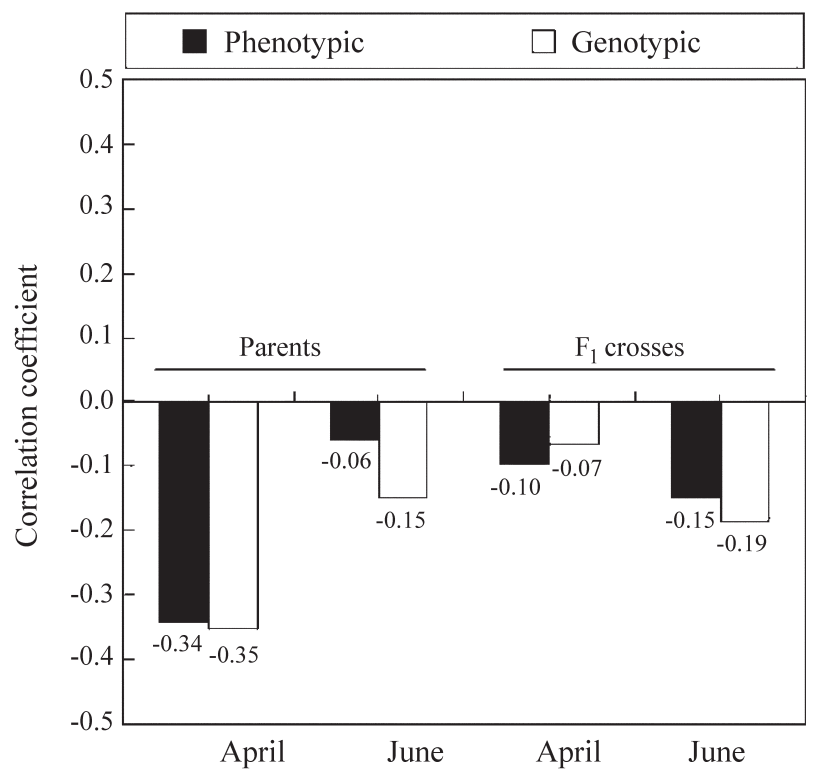

Figure 2 - Phenotypic and genotypic correlation coefficients between relative cell injury and heat tolerance index in upland cotton cultivars and hybrids under heat stressed and non-stressed field regimes.

additive and non-additive components under both heat stressed and non-stressed conditions. This finding is consistent with the report of Xu et al. (1998) on wheat but in- consistent with that of Ibrahim and Quick (2001b) and Sharma and Tandon (1998), who reported a predominance of additive type genetic variability and high heritability for CMT in wheat. A higher magnitude of additive genetic variability was, however, evident for whole plant heat tolerance (HTI) in the present study. A sizable magnitude of non-additive genetic variability and environmental interaction associated with the expression of CMT and HTI lowered their broadsense heritability estimates across environments. Low CMT heritability has also been observed in common beans (Marsh et al., 1985). Some studies have indicated higher genotypic differences for heat tolerance among plants previously exposed to moderately hot temperatures because of the high-temperature-acclimation potential (Li et al., 1991). However, the data produced in the present study did not reveal substantial differences in the magnitude of genetic variability for CMT measured under heat stressed and non-stressed regimes. This could partly be due to the suppressing effect of high temperature on the expression of CMT in some cultivars and hybrids as identified by Rahman et al. (2004).

Wide variation in heterotic expressions and combining ability effects observed for CMT and HTI in upland cotton suggested a multi-genic inheritance of these traits. This is incompatible with the single gene inheritance of heat tolerance as supported by the heat induced low pod set re- 
ported in cowpea (Marfo and Hall, 1992; Ismail and Hall, 1999). Maternal effects have also been reported to play a significant role in the inheritance of CMT in wheat (Ibrahim and Quick, 2001b). The present study did not investigate maternal effects on the inheritance of CMT or HTI in upland cotton. Experiments planned to ascertain the extent of any maternal effect in the inheritance of CMT and HTI in upland cotton could be helpful in further elucidating the inheritance mechanism of these traits.

Genetic association between traits helps in simultaneous improvement and indirect selection of the correlated traits. Marcum et al. (1998) established a strong relationship between CMT and whole plant heat tolerance as indicated by leaf firing and percent dry shoot weight in turf grass, expecting an opportunity of indirect selection of whole plant heat tolerance through CMT. However, my investigation with upland cotton did not find any significant correlation between tissue and whole plant heat tolerance at phenotypic or genotypic level, indicating that tissue and whole plant heat tolerance were independent of each other and represented two separate levels of heat tolerance in upland cotton. Lack of significant genetic correlation further reflected no relationship between the two traits due to genetic causes and also implies that genes controlling heat tolerance at cellular or tissue level are different from those controlling whole plant heat tolerance in upland cotton. These results reflect the possibility that the two traits could be genetically improved separately, and the recombinants could be obtained from the segregating populations following crosses of tissue tolerant and whole plant heat tolerant parents.

The conclusion is that although significant genetic variability existed for effective selection and genetic improvement of tissue and whole plant heat tolerance, the presence of substantial genotype $\mathrm{x}$ environment interaction and non-additive type genetic variability complicated the inheritance of the two traits in implicitly self pollinated upland cotton. Since cellular membrane thermostability (CMT) was not a good indicator of whole plant heat tolerance, the advantage of using CMT as a rapid in vitro technique could not be exploited efficiently in selecting whole plant heat tolerance. However, the CMT essay could be applied to reduce large segregating populations to a heat tolerant core for further evaluation and selection of agronomic and fiber quality traits. For such a purpose, the formula suggested by Tahir and Singh (1998) that reduces sample size to one-half without loosing efficiency could be very useful. Recurrent selection procedures for general combining ability should be a useful breeding approach in improving heat tolerance in upland cotton based on these traits.

\section{References}

Berry J and Bjorkman O (1980) Photosynthetic response and adaptation to temperature in higher plants. Annu Rev Plant Physiol 31:491-543.
Blum A and Ebercon A (1981) Cell membrane stability as a measure of drought and heat tolerance in wheat. Crop Sci 21:4347.

Blum A, Klueva N and Nguyen HT (2001) Wheat cellular thermotolerance is related to yield under heat stress. Euphytica 117:117-123.

Dickson MH and Petzoldt R (1989) Heat tolerance and pod set in green beans. J Am Soc Hort Sci 114:833-836.

Feaster CV and Turcotte EL (1985) Use of heat tolerance in cotton breeding. In: Proc Beltwide Cotton Prod Res Conf, Phoenix, AZ. National Cotton Council, Memphis, pp 364-366.

Hall AE (1992) Breading for heat tolerance. Plant Breed Rev 10:129-168.

Hall AE (1993) Physiology and breeding for heat tolerance in cowpea, and comparisons with other crops. In: George KC (ed) Adaptation of Food Crops to Temperature and Water Stress. Proceedings of an International Symposium, Asian Veg. Res. Dev. Center, Shanhua, pp 271-284.

Ibrahim AMH and Quick JS (2001a) Heritability of heat tolerance in winter and spring wheat. Crop Sci 41:1401-1405.

Ibrahim AMH and Quick JS (2001b) Genetic control of high temperature tolerance in wheat as measured by membrane thermostability. Crop Sci 41:1405-1407.

Ismail AM and Hall AE (1999) Reproductive-stage heat tolerance, leaf membrane thermostability and plant morphology in cowpea. Crop Sci 39:1762-1768.

Kempthorne O (1957) An Introduction to Genetic Statistics. John Wiley \& Sons, Inc. New York.

Kwon SH and Torrie JH (1964) Heritability and interrelationship among traits of two soybean populations. Crop Sci 4:196198.

Li PH, Davis DW and Shen Z (1991) High-temperature-acclimation potential of the common bean: Can it be used as a selection criterion for improving crop performance in hightemperature environments. Field Crops Res 27:241-256.

Lu ZM and Zeiger E (1994) Selection for higher yields and heat resistance in pima cotton has caused genetically determined changes in stomatal conductance. Physiol Plant. 92:273278.

Marcum KB (1998) Cell membrane thermostability and whole plant heat tolerance of Kentucky bluegrass. Crop Sci 38:1214-1218.

Marfo KO and Hall AE (1992) Inheritance of heat tolerance during pod set in cowpea. Crop Sci 32:912-918.

Marsh LE, Davis DW and Li PH (1985) Selection and inheritance of heat tolerance in common bean by use of conductivity. $\mathrm{J}$ Am Soc Hort Sci 110:680-683.

Martineau JR, Williams JH and Specht JE (1979) Temperature tolerance in Soybean-II. Evaluation of segregating populations for membrane thermostability. Crop Sci 19:79-82.

Rahman H (2004) Genetic basis of heat resistance in upland cotton (Gossypium hirsutum L.). Ph.D. Thesis, Institute of Pure and Applied Biology, Bahauddin Zakariya University, Pakistan.

Rahman H, Malik SA and Saleem M (2004) Heat tolerance of upland cotton during the fruiting stage evaluated using cellular membrane thermostability. Field Crops Res 85:149-158.

Raison JK, Berry JA, Armond PA and Pike CS (1980) Membrane properties in relation to the adaptation of plants to temperature stress. In: Turner NC and Kramer PJ (eds) Adaptation of 
Plants to Water and High Temperature Stress. John Wiley \& Sons, New York, pp 261-273.

Saadallah MM, Shanahan JF and Quick JS (1990) Heat tolerance in winter wheat: I. Hardening and genetic effects on membrane thermostability. Crop Sci 30:1243-1247.

Sharma RK and Tandon JP (1998) Cell membrane thermostability-II. An inheritance study in wheat. Agric Sci Dig Karnal 18:203-205.

Stevens MA (1979) Breeding tomatoes for processing. In: Cowell RW (ed) Proceedings of the $1^{\text {st }}$ International Symposium on Tropical Tomato. Asian Veg Res Dev Center Shanhua, Taiwan, pp 201-213.

Sullivan CY (1972) Mechanism of heat and drought resistance in grain sorghum and methods of measurement. In: Rao NGP and House LR (eds). Sorghum in the Seventies. Oxford and IBH Publishing Co., New Delhi.
Sullivan CY and Ross WM (1979) Selecting for drought and heat resistance in grain sorghum. In: Mussell H and Staple R (eds) Stress Physiology in Crop Plants. John Wiley \& Sons, New York, pp 263-281.

Tahir M and Singh M (1993). Assessment of screening techniques for heat tolerance in wheat. Crop Sci 33:740-744.

Talwar HS, Sekhar CA and Rao RCN (2002) Genotypic variability in membrane thermostability in groundnut. Indian J Plant Physiol 7:97-102.

Villareal RL and Lai SH (1979) Development of heat-tolerant tomato varieties in the tropics. In: Cowell RW (ed). Proceedings of the $1^{\text {st }}$ International Symposium on Tropical Tomato. Asian Veg Res Devel Center Shanhua, Taiwan, pp 188-200.

Xu RQ, Sun QX and Zhang SZ (1998) Studies on the combining ability and heterosis of cell membrane thermostability in common wheat. Acta Agronomica Sinica 24:55-60. Associate Editor: Márcio de Castro Silva Filho 